\title{
Jenny Slater, Youth and Disability - A Challenge to Mr. Reasonable (2015)
}

Murad Canbulut

Istanbul Kemerburgaz University

Follow this and additional works at: https://digitalcommons.uri.edu/mgdr

Part of the Anthropology Commons, Economics Commons, Marketing Commons, Medicine and Health Sciences Commons, Other Business Commons, and the Sociology Commons

\section{Recommended Citation}

Canbulut, Murad (2017) "Jenny Slater, Youth and Disability - A Challenge to Mr. Reasonable (2015)," Markets, Globalization \& Development Review. Vol. 2: No. 1, Article 9.

DOI: 10.23860/MGDR-2017-02-01-09

Available at: https://digitalcommons.uri.edu/mgdr/vol2/iss1/9

This Book Review is brought to you for free and open access by DigitalCommons@URI. It has been accepted for inclusion in Markets, Globalization \& Development Review by an authorized editor of DigitalCommons@URI. For more information, please contact digitalcommons-group@uri.edu. 
Jenny Slater, Youth and Disability - A Challenge to Mr. Reasonable (2015)

\section{Markets, Globalization \& Development Review}
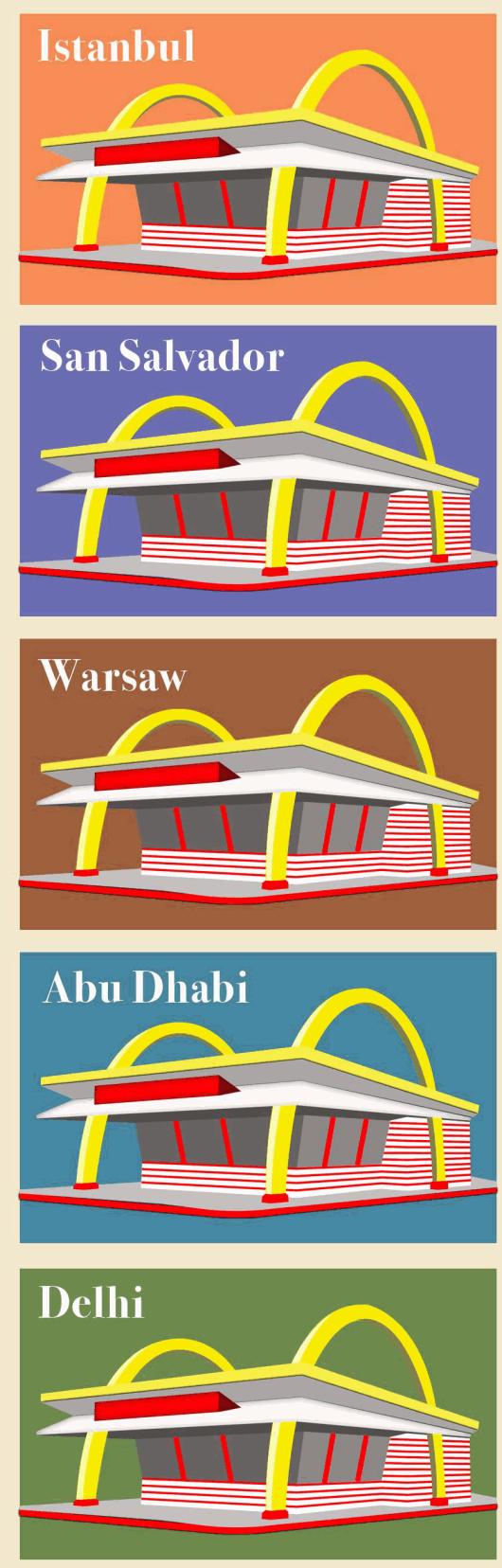
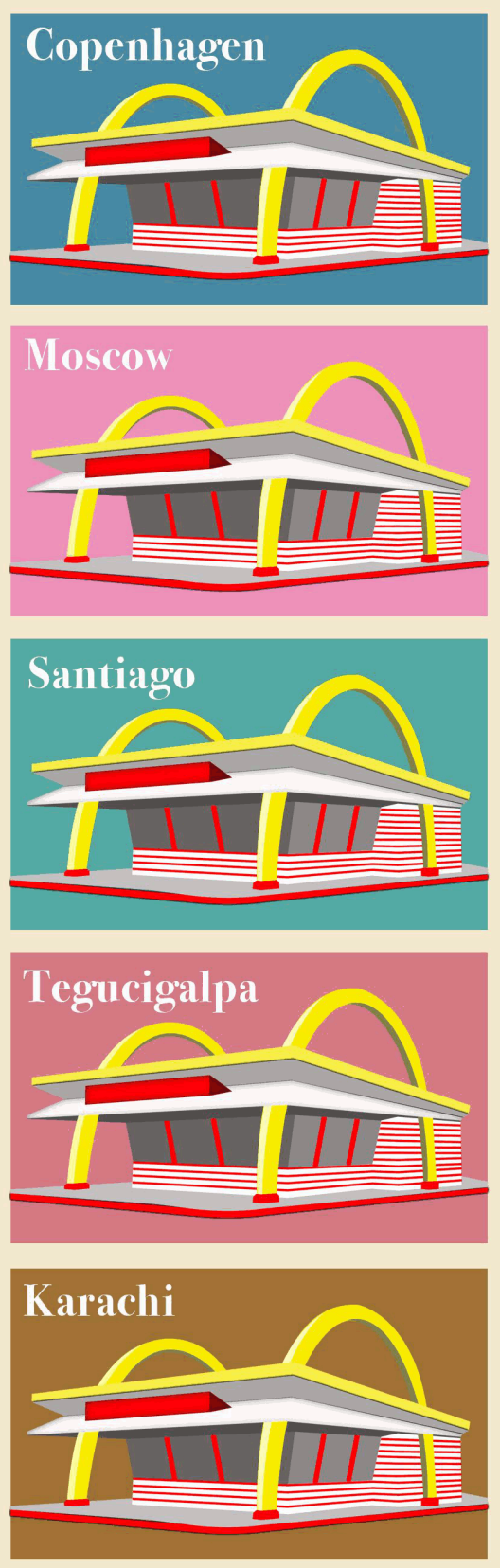
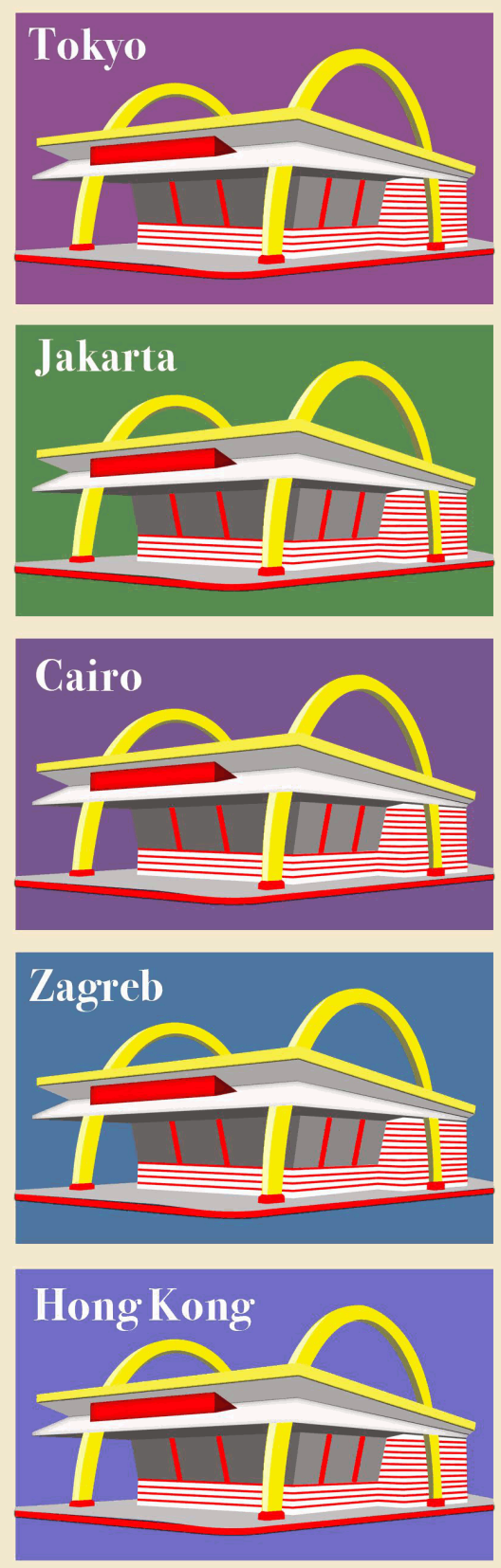

This book review is available in Markets, Globalization \& Development Review: https://digitalcommons.uri.edu/mgdr/ 


\section{Book Review}

\section{Slater, Youth and Disability-A Challenge to Mr. Reasonable (2015)}

As Dholakia and Atik (2016) emphasize in the opening article of MGDR, we may have to "live with" labels, such as advanced and emerging; rich, mid-income, and poor; etc. Although strict labeling can be problematic, as the authors suggest, it may be needed to be able to make distinctions in academic discussions, as well as in public policies. A similar problematic is happening in classifying people with labels and dualities, such as able and disabled, reasonable and unreasonable, since all these labels can be context- and time-dependent. In an effort to make the world a better place, Jenny Slater's book highlights an extremely sensitive topic: disability.

Jenny Slater is a Senior Lecturer at Sheffield Hallam University in UK, where the academic major 'disability studies' originated. Slater's work covers critical disability studies, queer theories and intersectional feminisms; she seeks to understand the relationships among disability, gender, sexuality, race and youth. With this book, she contributes to existing theoretical and empirical youth and disability literature. In March 2016, in celebration of the International Women's Day, she was one of the selected staff members at her university nominated for her work on gender and disability.

While disability may initially seem to be a very particular subfield, of study, mainly related to medicine, the topic in fact encompasses an interdisciplinary discussion on social relations, the body, power, citizenship, rights, and gender issues. Introducing disability studies to the marketing field, this review analyzes Slater's book, which takes a critical perspective on disability research. Slater writes:

"You are the creation of systems which prioritise certain ways of being over and above others. By functioning around pervasive, market-driven ideas of what is 'good', 'ideal' and 'normal', these global capitalist systems make your life appear as 'reasonable', whereas the lives of others around you are deemed "unreasonable" (p.1).

The above excerpt from the book is a part of a letter dedicated to an anonymous character in the book. Introducing the book with such a letter to this character, Mr. Reasonable, surprises and provokes the reader. At first, the reader really does not know who or what Mr. Reasonable is. As the journey starts, the reader realizes that Mr. Reasonable is the great authority who defines the norms and relationships; he is the system himself, which labels individuals solely in terms of their contributions to the production system. Mr. Reasonable is also the individual, the (neo)liberal adult, who can meet the 
predetermined norms of society and the market. The reader has the opportunity to get to know Mr. Reasonable in more detail in further chapters. Mr. Reasonable is able-bodied, white male who was born in a Western European or North American country.

In the second chapter, the main arguments of the book emerge. The reader begins to grasp the main actors of the discussion. For instance, with his emphasis on power, body, imprisonment, and gaze, Foucault is mentioned as an important figure for disability researchers.

In these first chapters, after emphasizing the difference between disability and impairment, and the birth of unreasonable body thought, the author addresses the barriers that disabled people face. For instance, since they have deficient bodies, they are excluded, and considered as a threat to the nation. The market system in general is far from creating peace and harmony because it creates different norms, thus excluding some from the system. Disability and impairment are concepts mediated by not only medical or bodily factors but also social, historical, economic, cultural, and political factors. The 'problem' of disability is detached from disabled people and considered as the product of unequal economic market relations. The book, in fact, is a critique of (neo)liberalism, not only in the case of disabled people, but also in the context of minorities who cannot meet the predetermined standards of the cruel system. In Foucauldian terms, unreasonable market actors are most likely to experience imprisonment. Poor, culturally or bodily different people are marginalized through (neo) liberal market practices.

By being given a sense of the dominant models of disability, the readers realize how the interpretation of disability has changed over the centuries. Within the (neo)liberal system, individuals have experienced freedom and imprisonment at the same time because - while promising equal rights for individuals - the system simultaneously excluded them from society and the market system for not fitting in with its ideals. For (neo)liberal doctrine, there is "intolerability towards differences" (Sothern 2007). Society in general, and the market and the state in particular, create negative attitudes towards physically deficient individuals, and pay little attention to their well-being.

For Slater, young individuals have a different place since youth is a turning point for participation in daily activities and joining society. Actually, the author states that being young has a symbolic meaning, emphasizing beauty, health, speed, and fluidity (Slater 2012). Since able-bodied and disabled young people watch the same television programs, and consume similar products, they are exposed to the same messages that emphasize how acceptable adults should behave and appear. If young people fail at meeting the desired outcomes, they are considered to threaten the well-being of the nation. Creating a healthy generation of young adults was considered key to a physically 
productive workforce who could also fight for their country if needed. 'Ability' (as a discourse of 'health') was a key feature of the late nineteenth century. From then, through the early $20^{\text {th }}$ century to $21^{\text {st }}$ century, contemporary Western thought pushes individuals embody characteristic of both 'whiteness' and 'masculinity' through all kind social relations and the market system, especially the media. Slater's insights into the creation of healthy generations are also echoed by citizenship scholars (e.g., Ustel 2009).

Being reasonable is not necessary solely for an individual's character, but also for their roles as consumers and citizens. Individuals evolve into commodities (Bauman cited in Giroux 2009, p.31), as the welfare state becomes the market state. The author's view of neoliberal societies as consumer societies is both novel and insightful, since most disability studies are exclusively associated with impairment and medical issues.

The fourth chapter opens up a discussion on the subjectivity of disabled people, who are assumed to depend on someone reasonable and non-disabled. Slater offers three readings in which she attempts to share some scenes of 'adulthood independence' of disabled individuals, and uses these as a basis for discussion. Since this section is presented as a dialogue, the sudden change on the flow may seem a bit confusing. The further parts investigate the role of power and dependence in the lives of disabled youths, focusing on their relations with parents, particularly mothers.

Chapter five particularly focuses on accessibility and ability issues. The accessibility issues are not just related to attitudinal barriers (e.g.; ignorance, pity, or inferiority) but also financial and informational barriers. The description of the comparisons between the lives of non-disabled and disabled youth show that "questions of access can arise for anyone, at any time, and anywhere for innumerable reasons" (Titchkosky 2011; p.4).

The conclusion chapter sheds much light on the relationship between capitalism and normalcy. Based on false promises of greater happiness, health, and completeness as an individual, in contemporary consumer society, females are associated with youth and beauty, while males are associated with muscles, mind, and reason. Slater critiques these imposed gender roles and appearances, as artifacts of Western creation. She concludes with a closing letter to Mr. Reasonable, which is a summary of the structure and discussions in the book. The liberal arguments are no longer acceptable in the context of the body. Most people have a belief that disability is a medical problem. In contrast, Slater directly discusses the body and disability issues as a critique of (neo)liberal thought. The labels are the creation of the system in which we live. In summary, 'Goodbye to Mr. Reasonable, goodbye to labels!' 
From a marketing perspective, I think two vital points are missing in the book. The first one is that Slater presents the state of disability in liberal times, but without providing any specific suggestions or solutions. She could have provided solutions or showed ways for survival. The second point is that she tends to overlook the impact of marketing in the (neo)liberal age. Marketing, as an institution, can be an important instrument that causes Mr. Reasonable either to exacerbate or to alleviate social problems. In other words, marketing elements can influence people in different directions (which can be regarded as the dark and the bright sides of marketing). On the dark side, by setting and imposing the norms and triggering consumption, marketing can create pressure on people to appear and act in certain ways, and thus promote materialism. Thus, in the case of disabled individuals or other minorities, marketing actors can negatively contribute to labeling and exclusion processes. On the bright side, marketing as an institution may help to remove some of the barriers, help vulnerable consumers to participate in society, and alleviate different societal problems. Through the tools of marketing, Mr. Reasonable can positively contribute to societal welfare and development if he really desires to do so. 


\section{References}

Dholakia, N. and Atik, D. (2016), "Markets, Globalization, Development: Charting the Intersections of Three Multipolar Concepts", Markets, Globalization and Development Review, 1 (1), Article 1.

Giroux, H. (2009), Youth in a Suspect Society: Democracy or Disposability? New York: Palgrave Macmillan.

Slater, J. (2012), "Youth for Sale: Using Critical Disability Perspectives to Examine the Embodiment of 'Youth', Societies, 2 (3), 195209.

Slater, J. (2015), Youth and Disability-A Challenge to Mr. Reasonable. Ashgate.

Sothern, M. (2007), "You Could Truly be Yourself if You Just Weren't You: Sexuality, Disabled Body Space, and the (Neo)liberal Politics of Self-help", Environment and Planning D: Society and Space, 25 (1), 144-159.

Titchkosky, T. (2011), The Question of Access: Disability, Space, Meaning. Toronto and London: University of Toronto Press.

Ustel, F. (2009), Türkiye Cumhuriyeti'nde Resmi Yurttaş Profilinin Evrimi. Modern Türkiye'de Siyasi Düşünce, İletişim. 